\title{
Geological factors in monitoring and planning nature trails at tourist centres in northern Finland
}

\author{
K. Lehtinen \& P. Sarala \\ Geological Survey of Finland
}

\begin{abstract}
Increasing tourism in northern Finland produces challenges for tourist centres, their land use plans and sustainable development. Increasing activities in areas that are sensitive to environmental changes need solutions for sustainable land use. Equipment to minimize environmental effects, and the planning of ecologically, culturally, and visually sustainable built up areas at popular tourist centres on the Ylläs and Levi fells are investigated in the LANDSCAPE LAB project. The project is partly financed by the EU LIFE Environment and the Geological Survey of Finland is involved as a partner. Geological factors such as the quality and composition of bedrock, the maturity of the matrix of surficial sediments, and geomorphology affect the resistance to erosion in different geoenvironments. In Fennoscandia, the glacial erosion has been intensive and the terrain is composed of eroded hill slopes and glacial landforms. Traditionally, in Finland, erosion resistance of nature trails has focused on vegetation and trampling resistance. The erosion rate is studied mainly by measuring the width and depth of the path and the amount of exposed roots and stones. Geological factors are not studied for nature trails, but geology and geological factors are the basic elements affecting resistance to erosion and should be included in land use planning. Careful planning and monitoring are the keys to creating visually impressive and geologically sustainable nature trails.
\end{abstract}

Keywords: erosion resistance, geological factors, nature trail, land use.

\section{Introduction}

Increasing tourism causes pressure on the land use planning and sustainable development of tourist destinations. Northern Finland tourist destinations have 
several thousands of kilometres of outdoor routes. These routes are situated in areas of different status like protected nature reserves, nature parks, state owned recreation areas and privately owned land. Many outdoor routes have multiple uses like, for example, nature trails for hikers, skiing and snow mobile routes and dog sled routes.

Outdoor routes that are used as nature trails can be classified in four groups:

1. Old, naturally formed summer routes, which are historical travelling routes;

2. Old, naturally formed routes that were developed as nature trails after the construction of guiding services;

3. Natural types of routes or other older routes, which have become nature trails when taken into multiple, round-the-year use because of increased tourism (for example some winter routes taken into nature trail use);

4. Other new outdoor routes, originally made for different purpose, but are afterwards used as nature trails (for example constructed skiing routes, which are used as nature trail at summer).

Nature trails at tourist destinations are situated in places that have something special to see. Speciality is often based on the geology of the area. Geological features like block fields, gorges, lateral channels, esker chains and hanging bogs are major components of fell landscape (Fig. 1). These features are the key to creating the perceptions of hikers and other tourists that these areas are unique. These geoenvironments are sensitive to erosion due to their geological properties. Furthermore, tourist destinations in northern Finland (Fig. 2) are situate in a severe climatic zone with four seasons; a short growing season in summer, frost heaving and frost weathering problems caused by the cold winter, erosion impacts of melt waters during spring and autumn rain. Thus, nature trails become sensitive to impact of increasing amounts of visitors. Nature trails used at spring and summer, are particularly sensitive to erosion problems.

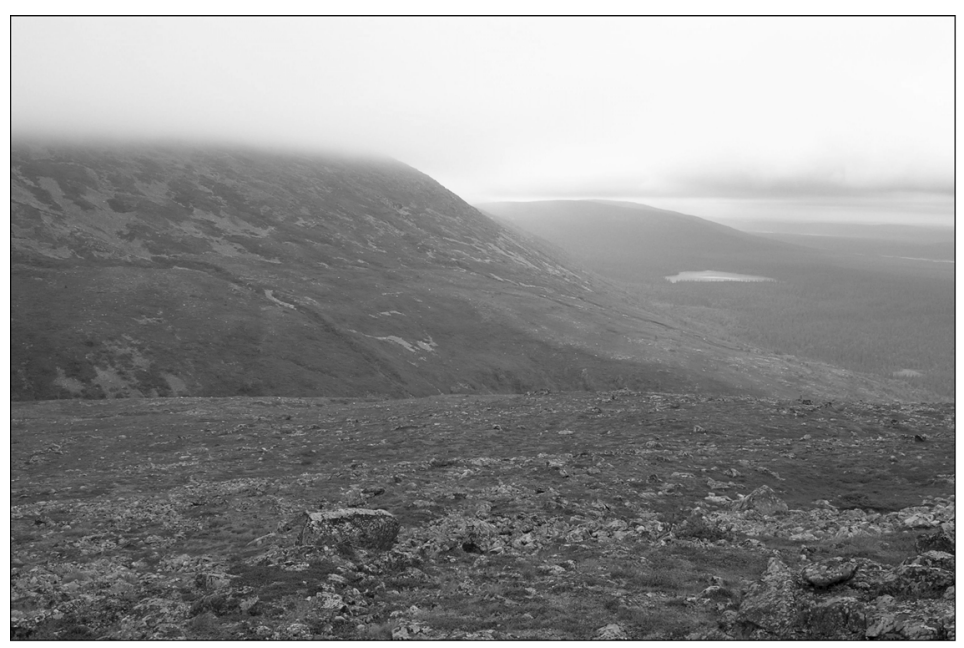

Figure 1: $\quad$ Scenery of highland on the Pallas fell. 


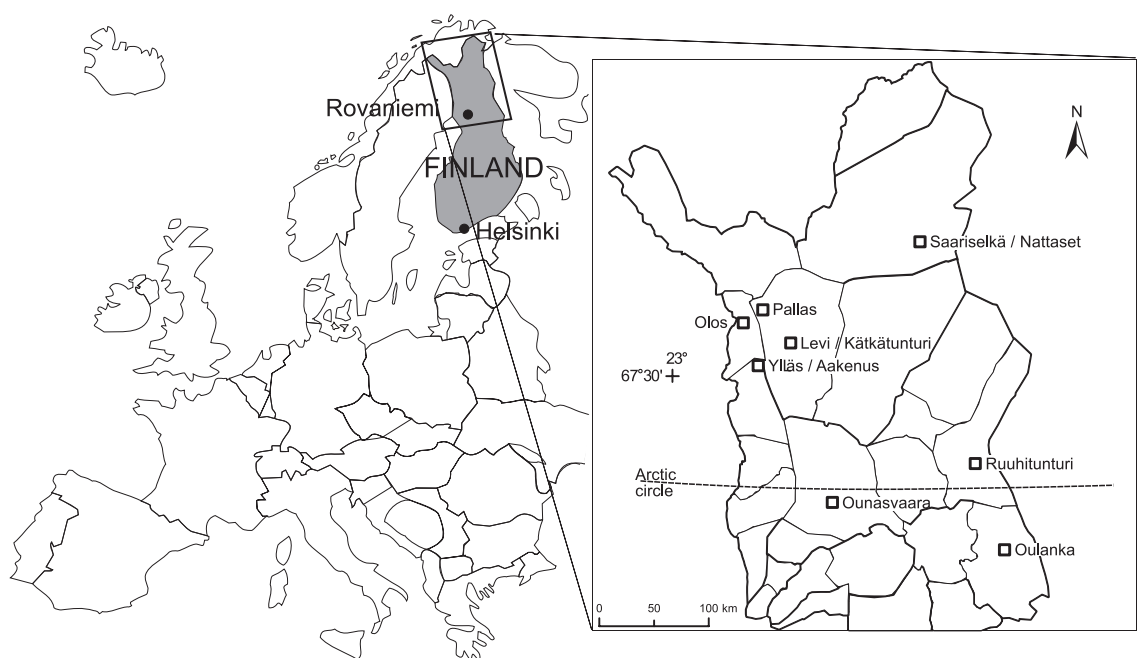

Figure 2: The location of study and target areas in northern Finland.

The effects of nature tourism on nature trails have traditionally studied in Finland using the trampling resistance of vegetation $[1,2,3]$. The erosion status of nature trails is also estimated by measuring the width and depth of the path and by the amount of exposed roots and stones. Several visitor studies were made $[4,5]$ concerning visitor counting and impact of the amount and the type of visitors at nature trails. Geological factors on the resistance to erosion in relation to natural trails have earlier been studied for example in Sweden and North America $[6,7]$ but not in Finland. Finnish studies concerning construction work and road building have been done, but the circumstances and objectives of these studies were different. However, geology is the basic factor affecting both vegetation and erosion resistance properties of the areas. For planning, monitoring and conservation of nature trails, geological factors and the geological history of the area must be studied. Things to investigate are the bedrock quality and composition, geomorphology, Quaternary deposits and their properties like maturity and composition of the matrix of surficial sediments.

Geological factors in land use and nature trail planning are studied by the Geological Survey of Finland as a part of the LANDSCAPE LAB project. The aim of the study is to investigate how and at what rate geological factors are affecting the resistance to erosion in different geological environments at tourist destinations in northern Finland. The objective is to develop a system to predict erosion effects and to develop a tool for nature trail planning and land use. Based on field and laboratory studies and visual examination, a classification of erosion resistance of different landform and soil types will be created and the equipment for monitoring erosion will be investigated. Furthermore, one other aim is to make recommendations for the planning of new nature trails and for suitable cover material for nature trails in different environments. 


\section{The Project LANDSCAPE LAB}

The project LANDSCAPE LAB (2004-2007) 'Tourist Destinations as Landscape Laboratories - Tools for Sustainable Tourism' is an EU LIFE Environment supported project situated in Finnish Lapland. The beneficiary is the University of Lapland and there are nine partner organizations and two municipalities involved in the project. The main target of the project is to determine solutions to sustainable land use, and to plan ecologically, culturally and visually sustainable built-up areas, where disadvantages caused by tourism, would be minimized. The main research areas are the fells of Ylläs and Levi, popular tourist centres in western Lapland.

The LANDSCAPE LAB Project consists of five tasks of which one concerns dissemination and management. The others are:

- The LABLAND task, in which the ecologically, culturally and visually sound urban structures at tourist destinations are studied. It makes landscape analyses in which the focus is on aspects like geology, landscape structure, history of land use, visual landscape, soundscape and landscape experiences.

- The LABECO task, in which the extent and types of the environmental impacts are studied to determine bio-indicators suitable for monitoring environmental effects for tourist destinations.

- The LABSOC task, where functional and social structures and activities of community are studied.

- The LABPLANT task, where usable and hardy plant species for sustainable restoration needs and landscaping in northern areas are sought. The task will select hardy plant species, develop methods of plant propagation and produce plant material for planting.

By combining all the data produced in the project, recommendations for use in the planning of tourist areas and implementation of environmental care will be presented.

\section{Study of geological factors}

\subsection{Geological environment}

The study area is situated in northern Finland and consists of nine geologically variable target areas (Fig. 2). The target areas have variations in bedrock quality and composition, geomorphology, glaciation history, Quaternary deposits and deepness of surficial sediments. The bedrock in Finland is part of Fennoscandian Shield, which is the oldest part in Europe (1.8-3.5 Ga). The bedrock consists mainly of quartzite, amphibolites, granulites and granites. In the study area, the rock types are quite resistant to erosion and are nowadays seen as fell areas at Finnish Lapland. The bedrock in the topographic depressions consists mainly of schist and greenstones [8, 9]. 
Finland was repeatedly covered by continental ice sheets over the last two and half million of years. Finland's position in the central area of the ice sheet and the variation in glacial dynamics have formed various Quaternary deposits and glacioerosional features [10]. Different kind of till beddings, moraine formations and glaciofluvial deposits were formed [11, 12, 13]. These features control land use and have an influence, for example, on the location of settlements and the formation of passages.

\subsection{Field and laboratory studies}

Field studies started at summer 2005. The status of erosion on nature trails was mapped by measuring the width and depth of the path and the amount of exposed stones and roots. In luxuriant areas, where soil is enriched of nutrients, vegetation is worn and roots are often exposed (Fig. 3). In barren areas, stones are usually exposed and impeding walking (Fig. 3). The erosion rate caused by approximately the same amount of visitors was not equal in different geoenvironments. Different kind of soils and Quaternary deposits are the key to studying erosion on nature trails. Mire and areas where bog formation is ongoing, and deposits like dunes and deflation areas (Fig. 4), are particularly sensitive to erosion. Nature trails in these areas need protective structures like duckboards and stairs to prevent erosion problems.
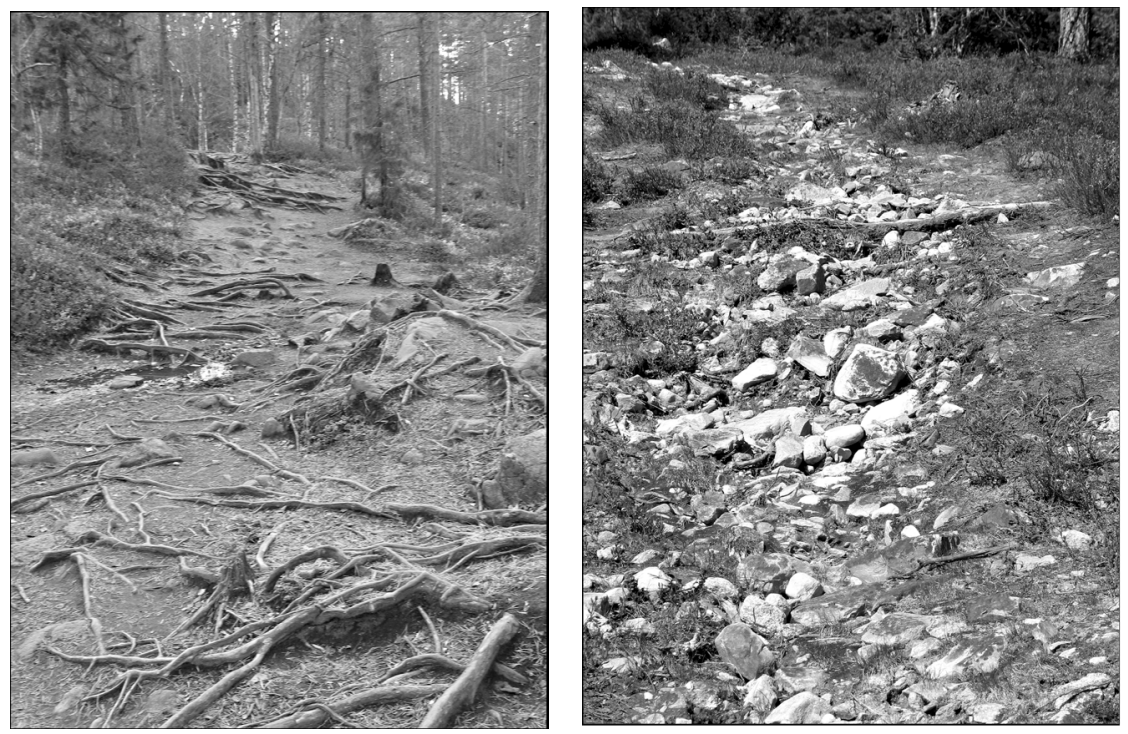

Figure 3: Exposed roots on nature trail at Oulanka (left); nature trail on moraine slope at Ylläs (right). Angular quartzite stones are exposed when fine material of moraine have been eroded.

One of the objectives is to study how suitable different cover materials are in different kinds of environments and how resistant they are against, for example, 
melt water erosion (Fig. 5) and their stability in variable slope steepness. The aim is to make recommendations for the use of cover material on nature trails in different areas. For this purpose, present cover materials were mapped and samples were taken at target areas. In some places, nature trails sensitive to erosion are protected with covering materials like bark chip, sawdust, gravel, mineral aggregate and stone ash (industrial product) to prevent erosion or to conserve the path. Preliminary results show that the bark chip and sawdust seem to be problematic, because they tend to stay wet for a long time after rain and melting of snow. Sawdust also is not an aesthetic material on a nature trail. Gravel and stone ash do not have a water content problem, but coarse gravel seems to be unstable on slopes (Fig. 5). In some places, stone ash seems to be a suitable covering material, but its use is not economic due to high transport distances and costs.

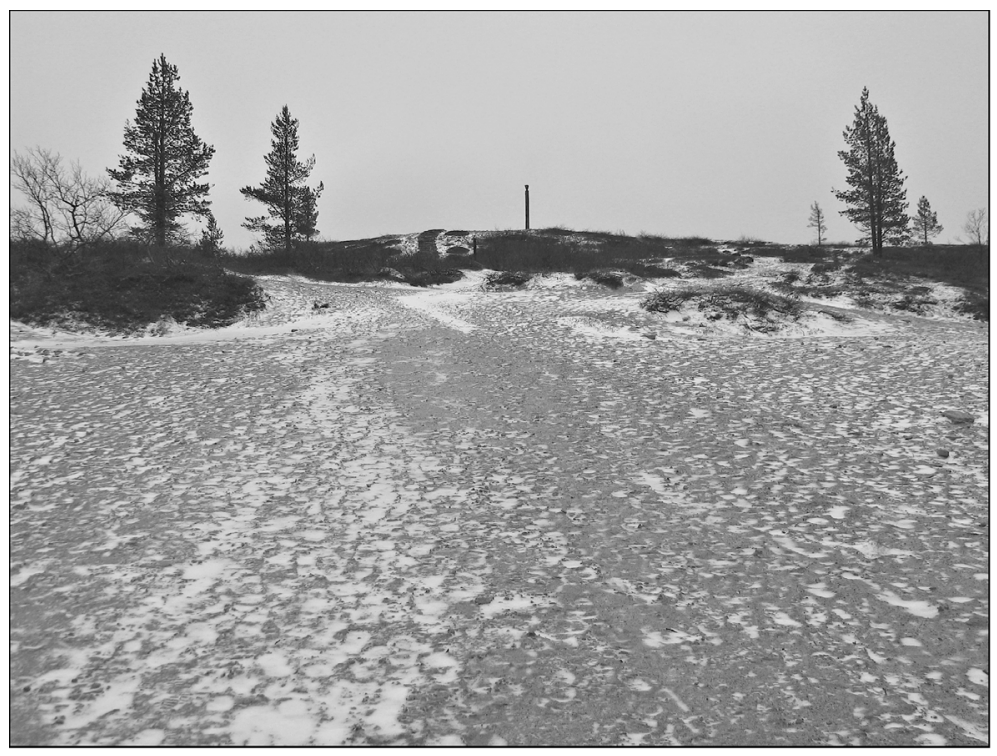

Figure 4: Deflation area on nature trail at Saariselkä.

The objective is also to define indicators for monitoring geological factors on nature trails and for estimating erosion potential in planning new trails. 3 to 6 sites on nature trails have been chosen from every target areas for soil sampling. The samples are taken from the surface layer (depth ca. $30 \mathrm{~cm}$ ) and analyzed to determine physical characteristics like matrix composition and maturity, weathering intensity, absorbing properties and frost heaving properties.

To develop a useful method for studying soil properties and their variations in the field, geophysical methods will be tested. Electrical conductivity will be measured at all the sites on the nature trail and beside the trails in early spring and autumn to study adsorption, permeability and compression properties. 

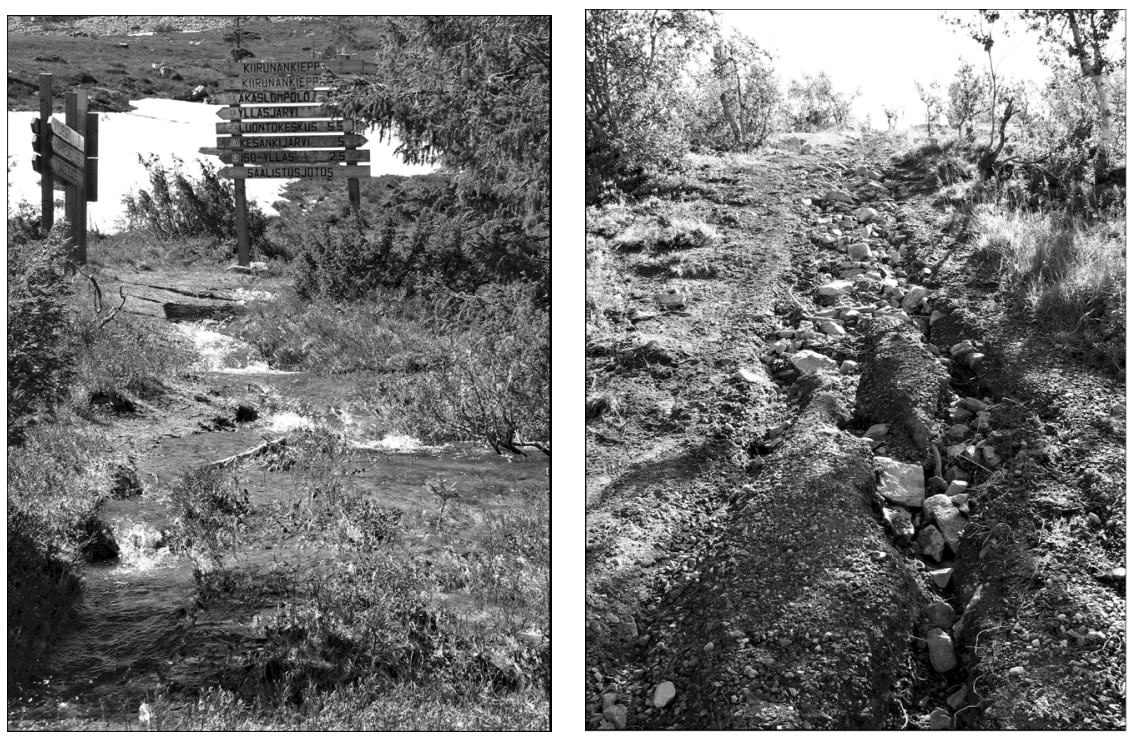

Figure 5: Nature trail at the Ylläs fell (left). Study areas are covered by snow about six months of the year. During spring, melt waters cause erosion problems on nature trails. Some trails act as drainage channels, particularly during spring when the soil does not absorb water because the ground is still partly frozen; example of erosion problems on nature trail caused by unsuitable cover material (right).

\section{Conclusions}

Significance of this study is to investigate measurable geological factors affecting the resistance to erosion on glaciated terrain. As a result, equipment and recommendations will be created for planning, monitoring and conserving nature trails at tourist destinations in northern Finland.

Preliminary results show that geological factors seem to have a significant impact on resistance to erosion on nature trails. The composition and quality of bedrock, depth of glacial overburden and grain size, stone content and quality of surficial sediment have a direct impact on absorption and permeability of soil. Stone content and quality of surficial sediments also affects the rate of wearing of fine-grained material at nature trails. However, soil and bedrock properties affect on vegetation and its luxuriance. To protect and conserve badly eroded or heavily loaded nature trails, it is important to find naturally looking but durable cover material.

\section{References}

[1] Tolvanen, A., Rämet, J., Siikamäki, P., Törn, A. \& Orell, M., Research on ecological and social sustainability on nature tourism in northern Finland, Working Paper of the Finnish Forest Research Institute 2, 2004. 
[2] Jämbäck, J., Aspects of ecological capacity: trampling tolerance and disturbance, Saarinen, J. \& Järviluoma, J. (eds.). Luonto virkistys- ja matkailu-ympäristönä. Metsäntutkimuslaitoksen tiedonantoja 619, pp. 143-163, 1996.

[3] Hoogster, M., The effect of trampling on vegetation at four cottages in Torne Lapland, northern Sweden. Report from Kevo Subarctic Research Station 19, pp. 25-34, 1984.

[4] Erkkonen, J., Jokimäki, J., Saarinen, J., Tuulentie, S. \& Virtanen, E. (eds.). Policies, Methods and Tools for Visitor Management. Proceedings of The Second International Conference on Monitoring and Management of Visitor Flows in Recreational and Protected areas, June 16-20.2004, Rovaniemi, Finland. Working Papers of the Finnish Forest Research Institute. 2004.

[5] Erkkonen, J. \& Sievänen, T., Standardisation of Visitor Surveys Experiences from Finland. Arnberger, A., Brandenburg, C. \& Muhar, A. (eds.). Monitoring and Management of Visitor Flows in Recreational and Protected Areas, Conference Proceedings p. 252-257, 2002.

[6] Bryan, R., The Influence of soil properties on degradation of mountain hiking trails at Grövelsjön. Geografiska annaler 59 A, pp. 49-65, 1977.

[7] Hammit, W., Cole, D., Wildland recreation, ecology and management. John Wiley \& Sons, 1998.

[8] Mikkola, E. Muonio-Sodankylä-Tuntsajoki. General Geological Map of Finland 1:400 000, Explanation to the Map of Rocks, sheets B7, C7, D7 (with an English summary). Helsinki: Geological Survey of Finland, 1941.

[9] Lehtonen, M., Airo, M-L., Eilu, P., Hanski, E., Kortelainen, V., Lanne, E., Manninen, T., Rastas, P., Räisänen, J., Virransalo, P., Kittilän vihreäkivialueen geologia, Lapin vulkaniittiprojektin loppuraportti, (summary in English), Geological Survey of Finland, Report of Investigation 140, 1998.

[10] Sarala, P., Glacial morphology and dynamics with till geochemical exploration in the ribbed moraine area of Peräpohjola, Finnish Lapland. PhD thesis. Geological Survey of Finland, 2005.

[11] Hirvas, H., Pleistocene stratigraphy of Finnish Lapland. Geological Survey of Finland, Bulletin 354, 1991.

[12] Kujansuu, R., On the deglaciation of western Finnish Lapland. Bulletin de la Comission Geologique de Finlande 232, 1967.

[13] Johansson, P, Kujansuu, R. (eds.), Pohjois Suomen maaperä: maaperäkarttojen 1:400 000 selitys (Quaternary deposits of Northern Finland - Explanation to the maps of Quaternary deposits 1:400 000) (summary in English), Espoo: Geologian tutkimuskeskus. 2005. 